УДК 101.1

DOI https://doi.org/10.32837/apfs.v0i32.1018

\author{
O. В. Гавва \\ ORCID ID: https://orcid.org/0000-0003-1230-8195 \\ аспірант кафедри філософії (PhD) \\ Національного технічного університету України \\ «Київський політехнічний інститут імені Ігоря Сікорського»
}

\title{
ЩОДО ПИТАННЯ ПРО ПОНЯТІЙНЕ РОЗРІЗНЕННЯ АКАДЕМІЧНОСТІ Й АКАДЕМІЗМУ
}

Постановка проблеми. Помічено, що в науковій літературі слова «академізм», «академічність» часто вживаються як рівнозначні, принаймні як синоніми. Наприклад, у тексті лекції «Соціальна філософія і методологія наукового дослідження» відомого дослідника філософії освіти М.І. Бойченка слова "академізм» та «академічність» ужиті в одному реченні й, вочевидь, мають один сенс (далі в цитаті курсив наш): «Соціальна філософія, як i філософія загалом, залишаються у своїй суті передусім акаделічнили, хоча для втілення й захисту цього класичного акаделізлу сучасне суспільство пропонує досить великий вибір новітніх засобів на додаток до класичних», а далі мова йде навіть про те, що «небезпек для академізму значно побільшало» [1]. Зі свого боку ми вбачаємо за доцільне в статті загострити увагу на розбіжності між цими словами, виявивши нюанс у слововжитку та запропонувавши тим самим два різнобарвні, протилежні за змістом терміни, визнаючи водночас, що на суто побутовому рівні їх змішування було й залишається цілком прийнятним і доречним.

У пригоді нам стане поняття перетвореної форми, що у вітчизняній філософії розроблялося насамперед Б. Новіковим, а також А. Мельниченком, Р. Богачовим, М. Шкепу. Перетворена форма є «об’єктивованою видимістю» [11, с. 68], і слово «видимість» тут уживається й у власне гегелівському значенні, як те, крізь що світиться сутність [3, с. 276], і в значенні М. Мамардашвілі: як те, де «пряме відображення змісту у формі <...> виключається» [9]. Перетворена форма є дечим таким, у чиєму прояві дійсна сутність відбивається ніби в кривому дзеркалі. Так, за Б.В. Новіковим, солідаризл є перетвореною формою солідарності, $€$ єдністю обмежених відповідальностей у взаємній безвідповідальності [11, с. 69]. Уся хитрість, уся підступність такого перетворення форми полягає в тому, що солідаризм і солідарність ми теж уживаємо як синоніми, тоді як сутнісно вони різняться, їх необхідно розрізняти. Солідаризм рядиться в солідарність і збиває з пантелику не лише філософа, а й, скажімо, пересічного громадянина, адже в певних обставинах цей слововжиток має не лише науковий, а й ідеологічний зміст.

Виклад основного матеріалу. Прикладаючи поняття перетвореної форми до досліджуваної нами теми, маємо змогу зробити суттєве (від слова «сутність») розрізнення. У філософії освіти академізм цілком може виступати як форма перетворена академічності, академізм у такому разі постає перед нами в значенні чи то квазі-, чи то псевдоакадемічності, але в будь-якому разі як певної удаваної, неістинної академічності - перетвореної академічності. Тобто, з одного боку, тут виступає академічність як відповідність науковим нормам заради діла самої науки, поступу людського пізнання, а з іншого - академізм як удаваність, ерзац такої відповідності, діяльність із імітації поступу. I перетворення форми може відбуватися тут із вражаючою швидкістю, про що дотепно написано у Франческо Петрарки:

«Наші часи щасливіші за древні, тому що тепер нараховують не одного, не двох, не сім мудреців, але в кожному місті їх, ніби скотів, цілі стада. I не дивно, що їх так багато, адже їх роблять так легко. До храму доктора приходить дурний юнак, щоб отримати знаки мудрості; його вчителі через любов або оману прославляють його; сам він величається, натовп мовчить, друзі та знайомі аплодують. Далі, за наказом, він сходить на кафедру й, позираючи на всіх із висоти, белькоче щось незрозуміле. Тоді старші навперебій підносять його похвалами, нібито він сказав щось божественне... По здійсненню цього з кафедри спускається мудрецем той, хто сходив на неї дурнем, дивовижне перетворення, невідоме й самому Овідію» [4, с. 23-24].

Звісно, ядучі слова Петрарки про дивовижне перетворення дурня на вченого - не рідкість у літературі. Над тими, хто під оплески «белькоче щось незрозуміле», справляючи тим самим враження вченого, сміялися в усі часи, а не лише в добу Гуманізму. У філософській літературі ми читаємо про це вже в Платона, де на протистоянні «невченого» мудреця Сократа 3 професійними мислителями-софістами побудовано чимало діалогів. Далі можемо згадати П'єра Абеляра, Миколу Кузанського, Еразма Роттердамського, Джордано Бруно, Дідро, Вольтера, Лессінга, Канта, Гегеля, Фейербаха, Маркса, узагалі всіх великих філософів, адже вони зазвичай протиставляли себе високочолій «ученій тупості» так само активно, як кафедральна високочолість відхрещувалася від цих людей. Дуже продуктивним нам убачається 
в подальшому розглянути цю «вчену тупість» разом із її антитезою - «невченою мудрістю», чи то пак «ученим незнанням», а то й «простацтвом» (М. Кузанський, Е. Роттердамський) в антитезі академічність-неакадемічність, оскільки це може відкрити інший кут зору й на антитезу академічність-академізм.

Наразі ж зосередимося саме на проблемі перетворення. Убачаємо, що подібне перетворення форми, перехід академічності в академізм і навпаки відбувається в історії повсякчас і ніколи не припиняється: історія науки доводить нам це. Більше того, почасти несприйняття саме академізму, свідома опозиція йому робила для науки й суспільства навіть більше, ніж могла зробити академічність, коли розглядати останню як елемент інституалізації науки, а не тільки як засіб їі нормування. За своєю природою академізм тяжіє до окостеніння, консервування, йому не потрібні зміни й будь-що, що ставить його під сумнів, тоді як наука й суспільне життя в цілому вимагають постійного розвитку, стрибків і вибухів. Через це академізм варто розглядати і як зворотній i необхідний бік цього розвитку, розглядати як того «мертвого, що хапає за ноги живого» .

Якщо розглядати окреслене нами перетворення в межах одного цілого явища (науки), то мусимо визнати й те, що академізм є необхідним моментом академічності, умовою та засобом для збереження, відтворення й розвитку науки принаймні одразу після того, як наука в істоpiї людства стала окремою специфічною сферою людської діяльності. Академічність як норма та як інституція «випадає в осад» академізму, що змушений, у свою чергу, маскуватися під академічність, імітувати їі, аби щоразу опинятися «на плаву». Головною причиною такого перетворення форми в академізм варто вважати суспільний розподіл праці, що, у свою чергу, є одним із проявів відносин приватної власності. «Знаки мудрості», про які каже Петрарка, потрібні задля того, щоб в ієрархічному суспільному розподілі праці мати більш шанований статус, де й власності побільше, а такі місця в основному віддані під ідеологів. Для чесного дослідника в цих обставинах нерідко єдиним виходом виявлялося бути поза інституцій та усталених норм, там, де ще можлива вільна думка й де «саме неакадемічні за формою твори нерідко реабілітовували філософію або навіть відкривали нові сторінки чи навіть епохи у філософуванні» [1]. Проте, як свідчить історія, щойно така неінституційність і неусталеність виборює кафедру, вона вимушена закріплювати свої досягнення, кристалізуючись якраз-таки в інституції; минулий час у цитаті поки що недоречний, адже цей процес відбувається й на наших очах.

Й оскільки як «академізм», так і «академічність» прямо виходять із поняття академії, повер- таючи нас до відомого закладу філософа Платона, питання академізму та академічності постає перед нами в іншому зрізі. Гарною ілюстрацією тут буде історія Французької академії: заснування цього закладу сприймається як визначна подія не лише для французької, а й для світової науки. На жаль, куди меншу увагу звертають на той факт, що засновник академії кардинал Рішельє виходив у її заснуванні аж ніяк не з революційних намірів, а «навіть дуже навпаки»: 3 бажання стримати суспільний прогрес у шкідливих для абсолютистської влади формах і направити його в корисні для неї.

Діалектика перетворення «корисного» на «некорисне» в цій історії запаморочлива; ми зупинимося лише на тій обставині, що, по суті, Рішельє ініціював створення Академії для протидії впливовому салону Отель Рамбуйє, який відіграв визначну роль у становленні французької літератури. «Французька Академія а організована в 1634 р. на основі літературного гуртка, що збирався в будинку вченого протестанта Валентина Конpapa (Valentin Conrart) і складався з представників буржуазної інтелігенції, які цікавилися питаннями мови й літератури. Оскільки в роботах цього гуртка були абсолютно відсутні ненависні першому міністрові кастово-аристократичні, опозиційні тенденції, що проявлялися, наприклад, в Отелі Рамбульє, Рішельє вирішив перетворити його на офіційну державну організацію, що має на меті створення загальнообов'язкового мовного й літературного кодексу, який відповідав би політичним завданням абсолютизму» . [7, с. 378]. Боротьба була настільки кулуарною та напруженою, що Рішельє не зупиняло навіть те, що об’єктом його ворожості ставав і Венсан Вуатюр, який був «найбільшою поетичною індивідуальністю Отеля Рамбульє, корифеєм французьких преціозних поетів» і водночас «не приймав жодних подачок від вельмож та отримував пенсію лише від Людовика XIII та його брата Гастона Орлеанського, у котрого він був на службі» [7, с. 372]. А Людовік XIII був «начальником» і для Рішельє! У цій боротьбі рахувалися з окремими персоналіями, лише беручи їх в оборудку: так, "до складу Академії, яка налічувала сорок членів, увійшло багато письменників, які були відвідувачами Отелю Рамбульє» [7, с. 378]. Інакше кажучи, їх удалося переманити й «перевербувати».

Наголосимо, що Отель Рамбуйє, до складу якого входила й письменниця Марі-Мадлен де Лафайет (авторка важливого для світової літератури роману «Принцеса Клевська», написаного нею в співавторстві з Ларошфуко), був свого роду продовжувачем справи академій у таких речах, які відповідали уявленням про вільний творчий дух Академії Платона навіть у дрібницях. «Отель Рамбульє засвоїв звичай італійських академій наділяти своїх співчленів пасторальними іменами. 
Так, маркізу Рамбульє називали Артенісою, їі дочку Жююлі - Меланідою...» тощо [7, с. 369], а сам цей гурток, де приділяли велику увагу дослідженню людських почуттів, теж відіграв важливу роль у становленні класицизму - художнього напряму, що згодом став естетичним оплотом абсолютистської аристократії, на який якраз-таки робив ставку Рішельє. Щодо Марі де Лафайет і Ларошфуко варто підкреслити, що вони, «сприйнявши художні відкриття класицизму, роблять крок уперед; їхня творчість має неоціненне значення для роману XVIII століття» [8, с. 275-276]. «Принцеса Клевська» ввійшла у всесвітню літературу як перший психологічний роман [8, с. 277], i це не робить слави вже Рішельє, що гнобив Отель Рамбуйє, вихованкою якого була Лафайет. Усе ж «головним оплотом літературної фронди проти абсолютизму був якраз Отель Рамбуйе, багато відвідувачів якого в подальшому взяли участь у збройній боротьбі проти абсолютизму» [7, с. 372], тому побоювання Рішельє були небезпідставними. Але виходить, що, знали про це відвідувачі салону мадам Рамбуйє чи ні, вони по факту все одно виявилися не проти класицизму, буде він супроводжуватися абсолютизмом чи ні, і в боротьбі того часу однаково робили визначні для людського поступу завоювання. Розібратися в цьому, не розуміючи логіки взаємопереходів і перетворень у розвитку, а лише сортуючи історичні явища на прогресивні та регресивні, неможливо, адже очевидно, що одне й те саме явище може бути водночас і прогресивним, і регресивним, або робитися прогресивним, щойно будучи регресивним, і навпаки.

У подальшому Французька академія поряд зі своєю, без сумнівів, проривною роллю для національної і світової науки відігравала в ній і відверто стримуючу роль: згадаймо лише, як академіки придушували передові для свого часу дослідження Пастера або Френеля! Розвиток науки тут міг відбуватися радше «всупереч», що тільки для буденного світогляду не значить водночас і «завдяки»: як писав Гегель, «той, хто тікає, ще не вільним, адже він у втечі все ще зумовлений тим, від чого тікає» [3, с. 233]. Без цієї жорстокої боротьби наука принаймні в межах наявного суспільного устрою просуватися не може, й академічність та академізм у ній будуть постійно маскуватися один під одного, ще й «ускладнюватися» різними неакадемічними формами продукування наукового знання, що також вступають у боротьбу.

Та й сам «академік» Платон, до слова, був консерватором, якщо не реакціонером: принаймні його «Закони» та «Політея» є відповіддю на історичну мінливість полісу, відображають бажання філософа уповільнити цей плин, ба навіть зупинити його, а ті явища в суспільному житті, що так обурюють мислителя, перемогти. Водночас «земною основою платонізму є, звісно, цілком зрозуміле побоюван- ня афінської аристократії, яка бачила, що виродження демократії в «охлократію» й «анархію», яке набувало саме в діяльності софістів свого філософсько-теоретичного вираження, загрожує місту великими бідами. Порятунок рідного полісу з його культурою Платон (що представляв, звісно, не лише себе, а й широке коло своїх однодумців) бачив у ствердженні авторитета деякої системи твердих принципів морально-політичного порядку, загальних норм поведінки та ставлення до подій того самого «єдиного» й «усезагального», що було розташоване та підведене під сумнів мисленням софістів» [6]. 3 огляду на це, Академія Платона явище в суспільному житті Афін революційне чи реакційне? Прогресивне чи регресивне? I на якому етапі розвитку як самої організації, так й античного суспільства? А яке значення Академії для філософії, тим паче академічної? Однозначної відповіді на питання тут немає й не може бути, проте зовсім не через те, що в ньому неможлива ясність. Однозначної відповіді тут годі шукати саме тому, що їі шукають тут суто розсудково, не діалектично, тобто не в перетворенні. «Регрес завжди залишається в такому уявленні чимось абсолютно протилежним прогресу, зворотнім до нього, якимось злом, прокляттям, яке, бачте, на жаль, існує поряд із таким «хорошим» явищем, як прогрес, і від якого бажано би позбавитися. Не в ліпшому становищі опиняється поняття «прогрес», яке розглядають окремо від регресу» [2, с. 107].

Насправді ж прогрес неможливий без регресу, а без них неможливий розвиток як такий: регрес є «консервативним моментом діалектики», без якого неможлива спрямованість розвитку, тобто здійснення його в певному напрямі [2, с. 112]. Але й це аж ніяк не значить, що між регресом і прогресом не варто встановлювати розбіжність, якщо мова йде про терміни, і віднаходити суперечність, протиріччя, якщо йдеться про поняття. Завдання - не в розділенні, а в розрізненні, без якого незрозумілою буде сама суть діла: коли історія науки повертається дослідникові то одним своїм боком, то другим, наприклад, то академічністю, то академізмом, ховаючи протилежний бік, проте відсвічуючи ним прямо в обличчя. Натомість «це ще не діалектика. Остання вимагає розглядати протилежності в один і той самий час і в одному й тому ж відношенні, де другий бік виступає як своє інше першого, як самозаперечуючий себе перший» [2, с. 109]. Через це варто вважати, що проблема - не виключно дихотомічний слововжиток пари «академізм-академічність», а й важливе методологічне питання, без прояснення якого неможливою стає свідома суспільна творчість.

Наостанок звернемо увагу на ще одну організацію, яка вважала себе спадкоємицею Академії Платона, - на так зване «коло Стефана Георге», GeorgeKreis. Про суть діяльності цього кола написано вже 
в передмові книги М. Маяцького «Спір про Платона». «Ця книга про те, як поет і декілька його соратників спромоглися кинути виклик університетській машині, «що відала Платоном», як складалася взаємодія між кафедрою та іншим, безпрецедентним, місцем знання та його виробництва» $[10$, с. 11]. Звісно, нюанси цього «виклику університетській машині» не вкладаються в похвальну фразу в передмові, а тому потребують пояснення.

У книзі ми читаємо, наприклад, що видний член осередку Георге професор Курт Зінгер, який «із майже релігійною завзятістю примикає до Кола» в 1912 році [10, с. 140], який написав книгу «Платон, засновник" у 1926 році, де, за відгуком рецензента, «чесно бореться за те, щоб увесь свій образ думок і весь свій світогляд заснувати на Платоні" $[10$, с. 146], та який, зрештою, стверджував, що «в Платоні треба впізнати та признати бійця в тій же боротьбі, що ії ведемо сьогодні ми: проти софістики як розпаду, розщеплення єдиного людського образу» $[10$, с. 145$]$, співчував націонал-соціалізму й у статті 1933 року позитивно оцінював італійський фашизм [10, с. 143]. Саме по собі «коло Георге», яке дійсно нагадувало вільний гурток із сильним лідером, власне, ним був сам Георге, якого називали Майстром, і навіть у своєму прообразі мало назву з відсилкою до Платона (так, автор пише про університетську общину Academia Urbana, що налічувала до 200 членів, і називає ï̈ «генеральною репетицією» "кола Георге» [10, с. 20-21]), спокутувало культ вождів, яким треба поклонятися і служити, не намагаючись їх розуміти. Щоправда, автор обережно зауважує, що те, «наскільки цей культ духовних і політичних вождів передбачав (чи навіть «наближав») грядущий націонал-соціалізм, $є$ однією з найбільш спірних і складних проблем rеopriaнських досліджень", i що сам Георге сповідував «політику аполітичного» $[10$, с. 25], але ця обережність усе рівно грає відверто проти «кола» й добре звертає нашу думку, як деколи прогресивні форми (такі як академія в початковому розумінні) можуть іти у фарватері найлютішої реакції типу фашизму, як свідоме уникнення політики теж опиняється політичною позицією, а боротьба проти «університетської машини» сама по собі ще нічого не значить, адже може бути боротьбою проти раціональності як такої, а навіть не проти ії специфічно академічної форми з властивими цій формі консервативними й часом негативними моментами (академізмом).

Щодо останньої обставини член «кола Георге» Залін у листі до Гадамера свідчить так: «Я б сказав, що в кола Георге взагалі не було жодних відносин із наукою. Георге був узагалі ворожим до наук (із повним правом, адже він був знайомий лише з в'ялою наукою рубежу віків), i, не рахуючи Гундольфа, у всьому старому колі ніхто, окрім Бьорінгера та Ландмана, не мав правильного розу- міння можливих результатів якої-небудь сутнісної науки». Далі Залін стверджує, що він навіть обстоював перед Георґе потребу робити посилання у власній роботі про Платона [10, с. 120], хоча питання науковості цієї роботи Заліна, наскільки можна судити із цитованої нами книжки, теж $\mathrm{e}$ «спірним і складним». Безперечним, на наш погляд, є хіба лиш те, що в різні часи платонівську Академію наслідували в чому завгодно, оскільки досі достеменно не відомо, чим саме та як займалися ії̈ члени протягом понад 900 років її історії: відомо лише те, що за часів Платона Академія тяжіла до суспільної діяльності [5, с. 26].

Висновки 3 дослідження. Установлення ясності в розрізненні академічності й академізму є неочевидним, але важливим питанням для досліджень у філософії та історії науки й освіти. Таке розуміння не лише дасть змогу краще та глибше розуміти й оцінювати природу тих процесів, що відбуваються в академічній науці й у виробництві людського знання в цілому, а й уникати в діяльності серйозних помилок. Це особливо актуально з огляду на зміни, що відбуваються в сучасній освіті та науці, адже вони мають стрімкий і докорінний характер, вимагають таких же швидких і водночас обгрунтованих рішень, які будуть скеровувати цей процес насамперед в академічному середовищі.

\section{Jimepamypa}

1. Бойченко М.І. Соціальна філософія і методологія наукового дослідження. URL: https://asp.knu.ua/doc/ Lektoriy/Social_Philosophy.pdf (дата звернення: 20.11.2021).

2. Босенко В.А. Всеобщая теория развития. Киев, $2001.470 \mathrm{c}$.

3. Гегель Г. Энциклопедия философских наук : в 3 т. Москва : Мысль, 1974. Т. 1 : Наука логики. 452 с.

4. Горфункель А.Х. Философия эпохи Возрождения : учебное пособие. Москва, 1980. 368 c.

5. Диллон Д. Наследники Платона: Исследование истории Древней Академии (347-274 гг. до н.э.). Санкт-Петербург : Изд-во С.-Петерб. ун-та, 2005. 281 с.

6. Ильенков Э.В. Античная диалектика как форма мысли. URL : http://caute.ru/ilyenkov/texts/phc/ antdia.html (дата звернення: 20.11.2021).

7. История французской литературы / ред. тома : И.И. Анисимов, С.С. Мокульский, А.А. Смирнов. Москва-Ленинград : Издательство Академии наук СССР, 1946. Т. 1 : С древнейших времен до революции 1789 года. $811 \mathrm{c.}$

8. Кожинов В.В. Происхождение романа. Москва : Советский писатель, 1963.440 с.

9. Мамардашвили М.К. Превращенные формы. URL: http://philosophy1.narod.ru/www/html/library/ $\mathrm{mmk}$ /forms.html (дата звернення: 20.11.2021).

10. Маяцкий М.А. Спор о Платоне: Круг Штефана Георге и немецкий университет. Москва : Изд. дом Высшей школы экономики, 2012. $344 \mathrm{c.}$

11. Новиков Б.В. Форма превращенная на марше. Отчуждение : сборник статей. Киев, 2009. С. 64-86. 


\section{Анотація}

Гавъа О. В. Щодо питання про понятійне розрізнення академічності й академізму. - Стаття.

У статті представлено авторський погляд на вжиток у філософії понять «академізм», «академічність» 3 опорою на поняття перетвореної форми в Б. Новікова й М. Мамардашвілі та діалектику прогресу і регресу у викладі В. Босенка. Актуальність звернення до проблеми випливає з необхідності вітчизняної освіти і науки відповідати на докорінні зміни й виклики, що відбуваються в цих сферах людської діяльності.

Суть питання, яке порушується в статті, полягає в потребі розрізнення понять «академізм», «академічність» як складників одного процесу творення наукового знання. Це необхідно з огляду на діалектичну складність самого цього процесу, у якому невіддільно переплетені прогресивні та регресивні моменти та які потрібно виділяти й розуміти для побудови цілеспрямованої та осмисленої діяльності в науці й освіті. Пропонується розглядати академізм як явище, що відповідає регресивному, консервативному моментові цього процесу, а академічність - як те, що відповідає прогресивному. При цьому ототожнення прогресу й регресу з, відповідно, позитивними чи негативними сторонами уникається.

Означена проблема ілюструється показовими епізодами $з$ історії організацій, так чи інакше пов'язаних із першопочатковим поняттям академії. Автор звертає увагу на неоднозначності в практиці, власне, платонівської Академії, Французької академії та так званого кола Стефана Георге. Для останніх двох організацій характерною рисою $є$ те, що їхня основа створювалася з осередків, які вважали себе спадкоємцями традицій Академії Платона. При цьому в статті підкреслюється, що ці традиції, суворо кажучи, теж були творчістю таких осередків, адже достеменно структура й порядок занять у платонівській Академії не відомі, та й сама Академія не могла протягом усього часу свого існування залишатися незмінною, щоб давати усталений зразок для наслідування. Відповідно до цього, одна й та сама структура - Академія Платона, що трактувалася як беззаперечно позитивне явище, могла бути використана для втілення будь-яких намірів її послідовників, що й наводиться в статті. Це є ще однією обставиною, що обгрунтовує висунуту ідею про уточнення слововжитку термінів академічності й академізму, особливо прикладаючи їх до неакадемічних форм продукування наукового знання.

Ключові слова: академізм, академічність, діалектика, прогрес і регрес, перетворена форма, Платонів- ська Академія, Французька академія, Отель Рамбуйє, коло Георґе.

\section{Summary}

Havva $O . V$. On the distinction between academical and academism. - Article.

This article presents author's viewpoint to the use of notions "academism" and "academical" in philosophy based on the notion "converted form" by B. Novikov and M. Mamardashvili and dialectics of progress and regress by V. Bosenko. Actuality of this problem is based on the necessity for domestic education and science to meet the changes and challenges happening in this field of mankind's activity.

The substance of article's issue lies in the need to distinguish between "academism" and "academical" as parts of the knowledge generation process. It is required according to dialectical complexity of this process, which intertwines progressive and regressive moments, so it is mandatory to distinguish and understand them in the practical and conscious activity in science and education. It is proposed to understand academical as a progressive moment and academism as a regressive. By that, the reduction of progress and regress to positive or negative moments is avoided.

This problem is illustrated by the demonstrational episodes from the history of organizations concerned with the original notion of academy. Author takes notice on the ambiguity of practice in Plato's Academy, French Academy, the George-Kreis. For the latter two organizations it is typical that their basis was created by the organizations which identified themselves as successors of Plato's Academy traditions. It is highlighted in this article that these traditions were, strictly speaking, created by these organizations, because the proper structure and order of lessons at Plato's academy still unknown. Moreover, Academy itself couldn't stay unchanged for all its existence to give an example for successors. According to that, structure of Plato's Academy was interpreted as undoubted positive thing, which was used to fulfil goals of its successors, even pointedly negative. This circumstance argues for the proposed idea to clarify the usage of notions "academism" and "academical", especially concerning non-academical forms of scientific knowledge generation.

Key words: academism, academical, dialectics, progress and regress, converted form, Plato's Academy, French Academy, Hotel de Rambouillet, the George-Kreis. 